\title{
Chronic haemolytic anaemia in hypertrophic cardiomyopathy
}

\author{
ALEXANDER ZEZULKA, LEONARD SHAPIRO, SHYAM SINGH \\ From the Department of Cardiology, Dudley Road Hospital, Birmingham
}

SUMMARY A patient with hypertrophic cardiomyopathy was found to have a chronic intravascular haemolytic anaemia. After investigation this was attributed to the abnormal haemodynamics of the cardiac disease. Treatment with propranolol was associated with an improvement in the anaemia. No further cases of haemolytic anaemia were found in 37 other patients with hypertrophic cardiomyopathy. It is concluded that haemolytic anaemia is a very rare feature of the condition.

Haemolytic anaemia due to intravascular trauma is not uncommon in patients with prosthetic heart valves but is rare in untreated acquired and congenital heart disease without endocarditis. ${ }^{1-3}$ We report a case of haemolytic anaemia associated with hypertrophic cardiomyopathy.

\section{Case report}

\section{HISTORY}

The patient, aged 28 years, had a systolic murmur diagnosed at birth. At 11 years old subaortic stenosis was diagnosed (resting gradient $100 \mathrm{~mm} \mathrm{Hg}$ ). The surgical findings were, however, of hypertrophic cardiomyopathy. Transaortic septal myomectomy was performed but did not change the outflow tract which remained at $100 \mathrm{~mm} \mathrm{Hg}$. At age 18 years, after the development of syncope and exertional breathlessness, a further cardiac catheterisation showed a resting outflow gradient of $46 \mathrm{~mm} \mathrm{Hg}$ with the angiographic features of hypertrophic cardiomyopathy and mitral regurgitation but with no aortic regurgitation. Later that year she had become pregnant and underwent hysterotomy. Two years later an early diastolic murmur suggesting mild aortic regurgitation was first heard. The following year she suffered from Streptococcus viridans endocarditis, which was successfully treated with penicillin and gentamicin. At the age of 26 years presyncope and exertional breathlessness increased, and paroxysmal nocturnal dyspnoea developed. Repeated 24 hour ambulatory electrocardiography showed frequent unifocal ventricular extrasystoles but no complex arrhythmias.

Requests for reprints to Dr A Zezulka, Department of Cardiology, Dudley Road Hospital, Birmingham B18 7QH.

\section{INVESTIGATIONS}

On examination she was pale with a regular jerky pulse and blood pressure of $120 / 65 \mathrm{~mm} \mathrm{Hg}$. The cardiac apex sound was sustained and of left ventricular type with atrial beat and systolic thrill. A widely radiating loud late ejection systolic murmur and an aortic decrescendo diastolic murmur and third and fourth heart sounds were heard.

The haemoglobin concentration was $9.6 \mathrm{~g} / \mathrm{dl}$ with $6 \%$ reticulocytes and fragmented red cells. Total bilirubin and total lactic dehydrogenase activity were raised and haptoglobin reduced. The serum iron concentration was $8 \mu \mathrm{mol} / \mathrm{l}$ (normal range 14.3$35.8 \mu \mathrm{mol} / \mathrm{l}$ ) and total iron binding capacity was $82 \mu \mathrm{mol} / \mathrm{l}$ (normal range $45-70 \mu \mathrm{mol} / \mathrm{l}$ ), suggesting chronic iron deficiency. Serum folate concentration was also low $(0.8 \mu \mathrm{g} / \mathrm{l}$ (normal range 2-14 $\mu \mathrm{g} / \mathrm{l}$ ); $1.8 \mathrm{nmol} / 1(9.1-31.7 \mathrm{nmol} / \mathrm{l})$ ) suggesting deficiency, and there was a relatively low serum $B_{12}$ concentration $(160 \mathrm{ng} / 1$ (normal range $150-900 \mathrm{ng} / \mathrm{l}$ ); $117.9 \mathrm{pmol} / 1$ (110.5-663.3 pmol/1)). After six weeks replacement therapy with iron, folate, and vitamin $B_{12}$ the haemoglobin concentration increased to $11.4 \mathrm{~g} / \mathrm{dl}$ with $3 \%$ reticulocytes and persistent red cell fragmentation.

Detailed investigations were carried out to confirm intravascular haemolysis and exclude corpuscular and extracorpuscular causes of haemolytic anaemia. ${ }^{4} \mathrm{At}$ this time the total bilirubin was $35 \mu \mathrm{mol} / 1$ (normal range $5-17 \mu \mathrm{mol} / \mathrm{l})$, total lactic dehydrogenase $510 \mathrm{IU} / 1$ (normal <500 IU/1), haptoglobins $0.12 \mathrm{~g} / 1$ (normal range $0.3-1.9 \mathrm{~g} / \mathrm{l}$ ), haemopexin $0.77 \mathrm{~g} / 1$ (normal range $0.51-1.15 \mathrm{~g} / \mathrm{l}$ ), and methaemalbumin negative. Plasma spectrophotometry showed deoxyhaemoglobin and oxyhaemoglobin, and analysis of two of five early morning urine samples showed 
haemosiderin. Chromium labelled red cell studies showed survival of 21 days (normal 25-35 days) with normal faecal blood loss $(0.9 \mathrm{ml}$ (normal $<1.2 \mathrm{ml}$ )). Labelled iron uptake by the marrow was avid, with iron utilisation of $107 \%$ (normal $65-85 \%$ ). There was no preferential liver or splenic isotope uptake, and marrow histology was normal.

No evidence was found for non-cardiac causes of haemolytic anaemia ${ }^{4}$ such as microangiopathy, red cell membrane and enzyme defects, abnormal haemoglobin, autoimmune phenomena, infection, drugs, toxins, ingestion of inorganic chemicals, neoplasia, hepatosplenic, renal, or intestinal dysfunction, and hypertension. Negative or normal results were found for differential and absolute white count, platelets, direct Coombe's test, red cell osmotic fragility, haemoglobin electrophoresis, Ham's test, glucose-6-phosphate dehydrogenase and pyruvate kinase activity, autohaemolysis test, Heinz body stain, cold agglutinin screen, Donath Landsteiner test, estimation of complement components $\mathrm{C} 3$ and $\mathrm{C} 4$, total haemolytic complement, fluorescent tremponemal antibody absorption, hepatitis B surface antigen, viral complement fixation screening, midstream urine and blood cultures, plasma urea and electrolyte concentrations, blood glucose and thyroxine concentrations, liver and cardiac enzymes, immunoglobulins and protein electrophoresis, serum lipids, serum ferritin, modified Schilling test for $\mathbf{B}_{12}$ absorption, and radiographs of the skull, hands, and long bone. Haemoglobin concentration was not

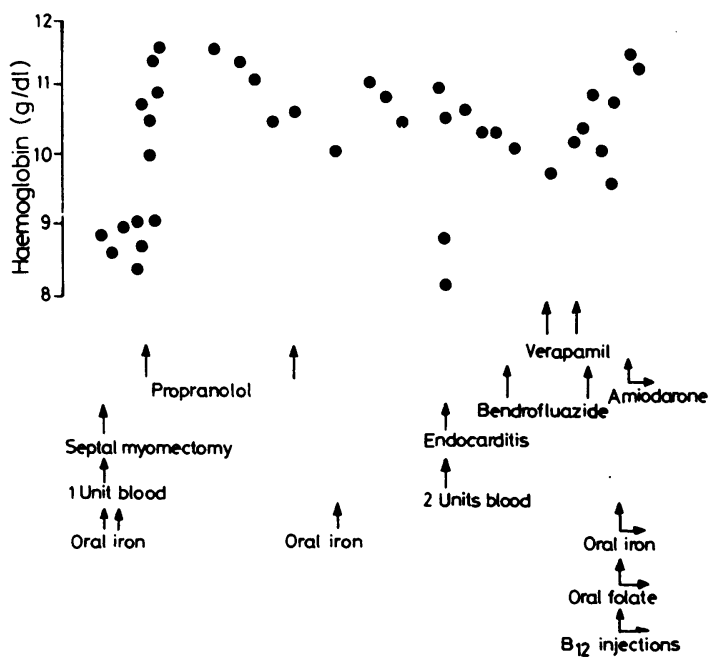

$\begin{array}{lllllllllllllllll}1967 & 68 & 69 & 70 & 71 & 72 & 73 & 74 & 75 & 76 & 77 & 78 & 79 & 80 & 81 & 82 & 83\end{array}$

Figure Relation of haemoglobin concentration to time and interventions. altered by bendrofluazide, verapamil, or amiodarone treatment (Figure).

\section{Comment}

The findings support a diagnosis of chronic intravascular haemolytic anaemia due to a cardiac cause. The mechanism of reduced red cell survival probably relates to abnormal turbulence and red cell shear stress. $^{5 n}$ Little haemolysis of normal red cells occurs at red cell shearing stress below $3000 \mathrm{dyn} / \mathrm{cm}^{2}$. Haemolysis is greatly increased above this level. The presence of outflow tract gradient provides a means of assessing red cell shear stress. In discrete aortic stenosis intravascular haemolysis may develop when pressure gradients of $>50 \mathrm{~mm} \mathrm{Hg}$ are present. ${ }^{7}$ If Bernoulli's equation is applied when peak systolic pressure gradient is $50 \mathrm{~mm} \mathrm{Hg}$ red cell shear stress equals $4000 \mathrm{dyn} / \mathrm{cm}^{2}$. This exceeds the limit of membrane tensile strength and can produce rupture or tear. $^{x}$

Our patient had untreated resting gradients of $100 \mathrm{~mm} \mathrm{Hg}$ at preoperative catheterisation and before and after septal myomectomy. Seven years later the untreated resting gradient was $46 \mathrm{~mm} \mathrm{Hg}$. This difference may be explained by the known lability of outflow gradient in hypertrophic cardiomyopathy. The shear stress generated at these pressures is sufficient to damage normal red cells.

A case of haemolytic anaemia in hypertrophic cardiomyopathy without endocarditis is reported in a study of left ventricular outflow obstruction on red cell survival. ${ }^{7}$ Here there was a left ventricular outflow gradient of $100 \mathrm{~mm} \mathrm{Hg}$, and after treatment with propranolol the haemoglobin concentration increased. In our case a rise in haemoglobin after propranolol treatment was also noted (Figure). Propranolol may reduce outflow gradients in some cases of hypertrophic cardiomyopathy thereby reducing red cell shear stress. Propranolol can, however, reduce blood viscosity and thereby influence red cell shear stress. In neither case was the effect of propranolol on outflow gradient measured. Outflow gradient may be labile in hypertrophic cardiomyopathy and thus may vary the shear stress, which possibly explains the intermittent haemosiderinuria observed. In a patient with rheumatic aortic and mitral valve disease red cell survival was normal at rest but reduced with regular daily exercise. ${ }^{9}$ The severity of haemolysis with an intracardiac prosthesis has been related to physical activity. " Thus even if obstruction were fixed such an additional factor might account for the variable red cell destruction and intermittent haemosiderinuria. If outflow gradient is labile when it increases haemolytic rate may increase. In turn the worsening anaemia produces haemodynamic effects leading to persis- 
tently increased outflow gradient and red cell shear stress. Correction of anaemia with possible consequent reduction of outflow gradient and haemolytic rate may explain why blood transfusion resulted in a prompt reduction of haemolysis in hypertrophic cardiomyopathy complicated by endocarditis. " It may also account for the stability of the haemoglobin concentration after propranolol withdrawal.

A further 37 of our patients with hypertrophic cardiomyopathy showed no evidence of haemolytic anaemia. ${ }^{12}$ It appears, however, that the association is causal and not merely fortuitous and we conclude that it is a very rare feature of the disease.

We thank the staff of the departments of haematology, biochemistry, and medical physics, Dudley Road Hospital, Birmingham.

\section{References}

1 Marsh GW, Lewis SM. Cardiac haemolytic anaemia. Semin Hematol 1969; 6: 133-49.

2 Morillo F, Senador G, Paravisini J. Mechanical hemolytic anemia after surgical correction of a congenital cardiomyopathy. F Cardiovasc Surg (Torino) 1980; 21: 68792.
3 Westphal RG, Azen EA. Microangiopathic hemolytic anemia due to congenital cardiovascular anomalies. JAMA 1971; 16: 1477-8.

4 de Gruchy GC. Clinical haematology in medical practice. 4th ed. Oxford: Blackwell, 1978.

5 Castleman B, McNeely BU, eds. Case records of Massachusetts General Hospital, Case 52-1964. N Engl f Med 1964; 271: 898-905

6 Brodeur MTH, Sutherland DW, Koler RD, et al. Red blood cell survival in patients with aortic valvular disease and ball valve prostheses. Circulation 1965; 32: 570-6.

7 Jacobson RJ, Rath CE, Perloff JK. Intravascular haemolysis and thrombocytopenia in left ventricular out-flow obstruction. Br Heart $\mathcal{F}$ 1973; 35: 849-54.

8 Nevaril CG, Lynch EC, Alfrey CP Jr, Hellums JD. Erythrocyte damage and destruction induced by shearing stress. F Lab Clin Med 1968; 71: 784-90.

9 Miller SD, Mengel CE, Kremer WB, Gutterman J, Senningen $R$. Intravascular hemolysis in a patient with valvular heart disease. Ann Intern Med 1966; 65: 210-5.

10 Sears DA, Crosby WH. Intravascular hemolysis due to intracardiac prosthetic devices, Diurnal variations related to activity. Am f Med 1965; 39: 341-54.

11 Solanki DL, Sheikh MU. Fragmentation hemolysis in idiopathic hypertrophic subaortic stenosis. South Med $\mathcal{F}$ 1978; 71: 599-601.

12 Shapiro LM, Zezulka A. Hypertrophic cardiomyopathy. "A common disease with a good prognosis": 5 year experience of a district general hospital. Br Heart $\mathcal{f}$ 1983; 50: $530-3$. 